\title{
DRG2 Depletion Promotes Endothelial Cell Senescence and Vascular Endothelial Dysfunction
}

\author{
Anh-Nhung Le ${ }^{1,+}{ }^{\mathbb{D}}$, Seong-Soon Park ${ }^{1,+}$, Minh-Xuan Le ${ }^{1,+}{ }^{\mathbb{D}}$, Unn Hwa Lee ${ }^{1}$, Byung Kyun Ko ${ }^{2}$, \\ Hye Ryeong Lim ${ }^{3}$, Ri Yu ${ }^{4}$, Seong Hee Choi ${ }^{5}$, Byung Ju Lee ${ }^{1}$, Soo-Youn Ham ${ }^{6, *(D)}$, Chang Man Ha ${ }^{3, *}$ \\ and Jeong Woo Park ${ }^{1, *}$
}

1 Department of Biological Sciences, University of Ulsan, Ulsan 44610, Korea; leanhnhung1996@gmail.com (A.-N.L.); tptp3123@naver.com (S.-S.P.); lmxuan309@gmail.com (M.-X.L.); unnhwa@naver.com (U.H.L.); bjlee@ulsan.ac.kr (B.J.L.)

2 Department of Surgery Ulsan University Hospital, University of Ulsan, Ulsan 44033, Korea; byungkyuko@naver.com

3 Research Strategy Office and Global Relation Center of Korea Brain Research Institute, Daegu 41062, Korea; hrsz@kbri.re.kr

4 Neurovascular Biology Laboratory, Neurovascular Unit Research Group, Korea Brain Research Institute, Daegu 41062, Korea; haru_y@kbri.re.kr

5 RopheLBio, B102, Seoul Forest M Tower, 31, Seongdong-Gu, Seoul 04778, Korea; nacchal2@naver.com

6 Department of Radiology, Sungkyunkwan University Kangbuk Samsung Hospital, Seoul 03181, Korea

* Correspondence: syohammd@hanmail.net (S.-Y.H.); changman@kbri.re.kr (C.M.H.); jwpark@ulsan.ac.kr (J.W.P.)

+ These authors contributed equally to this work.

check for

updates

Citation: Le, A.-N.; Park, S.-S.; Le,

M.-X.; Lee, U.H.; Ko, B.K.; Lim, H.R.;

Yu, R.; Choi, S.H.; Lee, B.J.; Ham,

S.-Y.; et al. DRG2 Depletion Promotes

Endothelial Cell Senescence and

Vascular Endothelial Dysfunction.

Int. J. Mol. Sci. 2022, 23, 2877.

https://doi.org/10.3390/

ijms23052877

Academic Editor: Saša Frank

Received: 30 January 2022

Accepted: 2 March 2022

Published: 6 March 2022

Publisher's Note: MDPI stays neutral with regard to jurisdictional claims in published maps and institutional affiliations.

Copyright: (C) 2022 by the authors. Licensee MDPI, Basel, Switzerland. This article is an open access article distributed under the terms and conditions of the Creative Commons Attribution (CC BY) license (https:// creativecommons.org/licenses/by/ $4.0 /)$.

\begin{abstract}
Endothelial cell senescence is involved in endothelial dysfunction and vascular diseases However, the detailed mechanisms of endothelial senescence are not fully understood. Here, we demonstrated that deficiency of developmentally regulated GTP-binding protein 2 (DRG2) induces senescence and dysfunction of endothelial cells. DRG2 knockout (KO) mice displayed reduced cerebral blood flow in the brain and lung blood vessel density. We also determined, by Matrigel plug assay, aorta ring assay, and in vitro tubule formation of primary lung endothelial cells, that deficiency in DRG2 reduced the angiogenic capability of endothelial cells. Endothelial cells from DRG2 KO mice showed a senescence phenotype with decreased cell growth and enhanced levels of p21 and phosphorylated p53, $\gamma \mathrm{H} 2 \mathrm{AX}$, senescence-associated $\beta$-galactosidase (SA- $\beta$-gal) activity, and senescence-associated secretory phenotype (SASP) cytokines. DRG2 deficiency in endothelial cells upregulated arginase 2 ( $A r g 2)$ and generation of reactive oxygen species. Induction of SA- $\beta$-gal activity was prevented by the antioxidant $\mathrm{N}$-acetyl cysteine in endothelial cells from $D R G 2 \mathrm{KO}$ mice. In conclusion, our results suggest that DRG2 is a key regulator of endothelial senescence, and its downregulation is probably involved in vascular dysfunction and diseases.
\end{abstract}

Keywords: DRG2; endothelial cells; senescence; angiogenesis; vascular dysfunction

\section{Introduction}

Endothelial cells lining the interior surface of blood vessels regulate blood flow in vascular circulation [1], playing an important role in vascular function [2]. Angiogenesis, the formation of new capillaries from pre-existing blood, is primarily undertaken by endothelial cells [3]. Endothelial dysfunction impairs angiogenesis and contributes to the increased prevalence of cardiovascular diseases [4]. Therefore, understanding the basis of endothelial dysfunction has important implications for understanding and managing cardiovascular disease.

Cellular senescence is characterized by cell-cycle arrest and pro-inflammatory changes in gene expression [5]. The senescence of endothelial cells leads to endothelial dysfunction [6]. Senescence can be induced by various kinds of stimuli, including ionizing ra- 
diation [7], telomere dysfunction [8] or reactive oxygen species (ROS) [9]. Among these, oxidative stress plays a central role in the development of cellular senescence [10]. Oxidative stress occurs when the production of ROS overwhelms endogenous antioxidant systems and/or when endogenous antioxidant systems are impaired [11,12]. Although oxidative stress is a major factor in the onset of senescence [13], the specific mechanisms underlying ROS-induced endothelial senescence are not clear.

In the endothelium, endothelial nitric oxide synthase (eNOS) uses L-arginine as a substrate to produce nitric oxide $(\mathrm{NO})$, which plays a protective physiological role in the vasculature [14]. Arginase 2 (Arg2), a predominant isoform of arginase in endothelial cells [15], competes directly with eNOS for L-arginine to inhibit NO synthesis [16]. Upregulation of Arg2 decreases intracellular L-arginine content to reduce NO production and increases the production of ROS by eNOS uncoupling [17,18]. Thus, Arg2 plays an important role in endothelial dysfunction with implications in vascular disease [19].

Developmentally regulated GTP-binding proteins (DRGs) constitute a subfamily of the GTPase superfamily [20]. The DRG subfamily consists of two closely related proteins, DRG1 and DRG2 [21]. DRG1 and DRG2 interact with different molecules, DRG family regulatory protein 1 (DFRP1) and DFRP2, respectively [22], suggesting that they have distinct functions. Previously, we found that overexpression of DRG2 affects cell proliferation and apoptosis in Jurkat human T cells [23,24], inhibits $\mathrm{T}_{\mathrm{H}} 17$ differentiation, and ameliorates experimental autoimmune encephalomyelitis in mice [25]. We also learned that DRG2 interacts with Rab5 on endosomes and is required for Rab5 inactivation on endosomes and for recycling of transferrin (Tfn) to the plasma membrane [26]. Recently, it was shown that DRG2 knockdown induces Golgi fragmentation [27] and mitochondrial dysfunction [28], decreases the stability of Rac1-positive membrane tubules in cancer cells [29], and suppresses VEGF-A production in melanoma cells, leading to inhibition of tumor angiogenesis [30]. Knocking out DRG2 impairs dopamine release from dopamine neurons in the mouse brain [31]. Together, these data demonstrate that DRG2 is an important regulator of signal pathways for cell growth, differentiation, and/or vesicle trafficking. However, little is known about the functional role of DRGs in endothelial cells.

In this study, we examined the role of DRG2 in the regulation of endothelial-generated ROS and endothelial senescence. We demonstrated that DRG2 depletion increases NADPH oxidase 2 (NOX2) expression, ROS generation, and senescence in endothelial cells. In addition, we found that DRG2 deficiency reduces the angiogenic activity of endothelial cells, lung blood vessel density, and blood flow in the cerebral brain. Together, these results suggest that $D R G 2$ deficiency leads to endothelial dysfunction and impaired angiogenesis through upregulation of ROS and senescence in endothelial cells.

\section{Results}

\subsection{DRG2-/- Mice Exhibit Decreased Microvascular Circulation and Blood Vessel Density}

We previously demonstrated that $D R G 2$ depletion in cancer cells suppresses tumor angiogenesis [30]. In the current study, we further investigated the effects of DRG2 depletion on endothelial cell behavior in mice. As a functional parameter, we determined whether $D R G 2$ deficiency affects the microvascular circulation by evaluating the velocity of blood flow in the cerebral cortex of wild-type and $D R G 2^{-/-}$mice under normal conditions using laser speckle flowmetry. The results showed that the cerebral blood flow (CBF) of the ipsilateral cortex of $D R G 2^{-/-}$mice decreased to $72 \%$ of that in wild-type mice (Figure $1 \mathrm{~A}$ ). The time course of the relative changes in $\mathrm{CBF}$ for vascular compartments is shown in Figure 1B. No significant change in CBF level of wild-type or DRG2-/- mice were detected over the periods observed (Figure 1B), which suggests that microvascular circulation was stable in both wild-type and $D R G 2^{-/-}$mice. The CBF level of $D R G 2^{-/-}$mice was significantly lower than that of wild-type mice over the periods observed (20 s) (Figure 1B). We next determined whether DRG2 deficiency affects the blood vessel density in lung tissues. The sections of lung tissues from wild-type and $D R G 2^{-/-}$mice were stained to detect CD31, a vascular endothelial cell marker. A representative lung section stained with anti-CD31 
antibody is shown in Figure 1C,D, with quantitation of vessel area and microvessel number. The immunohistological analysis confirmed significantly reduced blood vessel density, measured as a reduced percentage in CD31-positive vessel area (Figure 1C), as well as a reduction in microvessel number (Figure 1D) in the lung of $D R G 2^{-/-}$mice compared with that of wild-type mice. These results indicate that $D R G 2$ deficiency decreases microvascular circulation and blood vessel density in mice. Defects in microvascular circulation and blood vessel density can lead to an increase in cardiovascular diseases [4]. Consistently, we reported growth retardation and shortened lifespan in DRG2 ${ }^{-/-}$mice [31]. We next determined whether DRG2 deficiency affects the reproduction of mice. We found that the number of progeny per litter of $D R G 2^{-/-}$mice was significantly less than that of WT mice (Figure 1E).

A
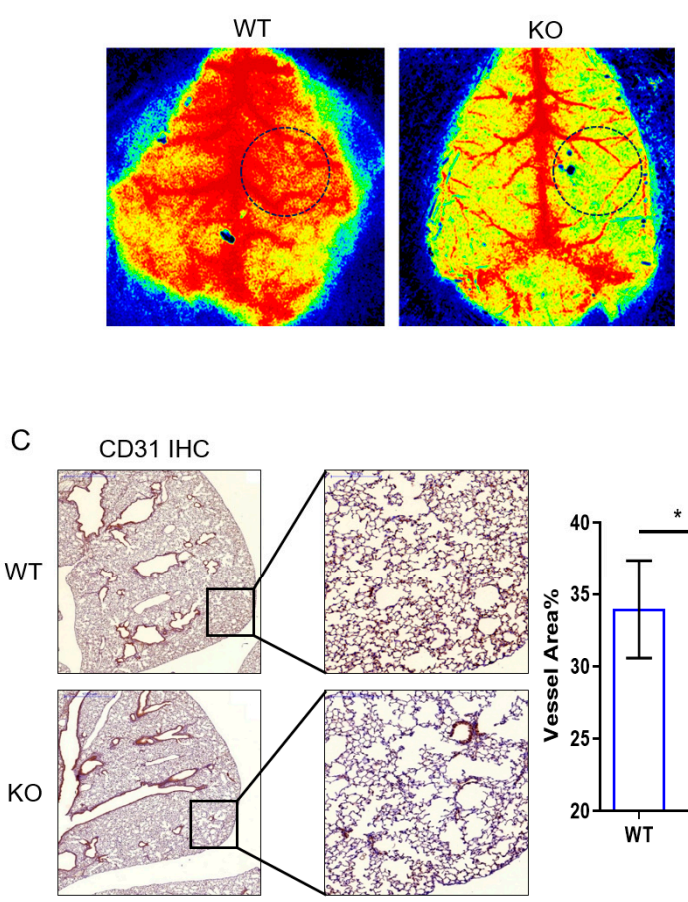
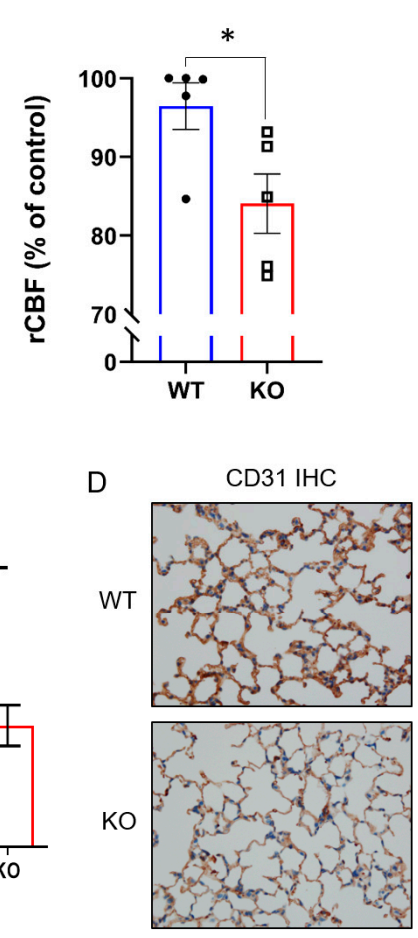

B

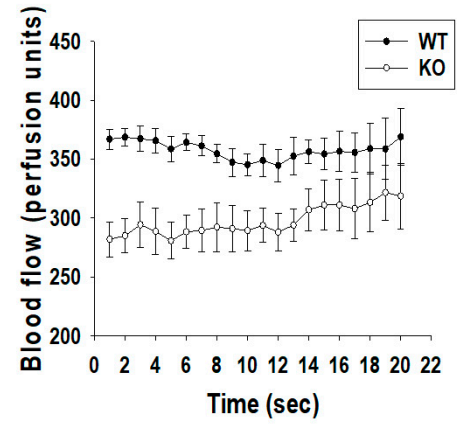

E

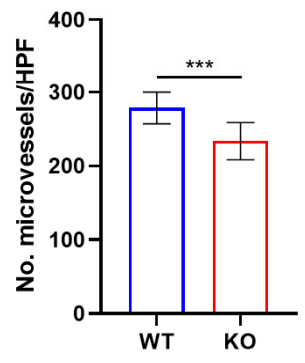

Figure 1. Effects of DRG2 deficiency on cerebral blood flow (CBF) and lung blood vessels density. $(\mathbf{A}, \mathbf{B})$ Effect of DRG2 deficiency on CBF. (A) Representative laser speckle images of cerebral blood perfusion in wild-type (WT) and DRG2 $2^{-/}(\mathrm{KO})$ mice. All images show areas of high and low blood perfusion as yellow-red and blue-black, respectively. CBF in the cerebral cortical area was calculated from the circular region-of-interest (ROI) (black dotted line) and quantified ( $\mathrm{n}=5$ mice/group). ${ }^{*} p<0.05$. (B) The time courses change in CBF at the circular ROI of the cerebral cortical area ( $\mathrm{n}=5$ mice/group). (C,D) Effect of DRG2 deficiency on blood vessel density in mouse lung. (C) Representative microscopic images of CD31 immunohistochemistry in mouse lungs (original magnification, $10 \times$ and $40 \times$, respectively) with quantification of vessel area fraction. The data are expressed as the mean \pm SEM ( $n=15$ areas from 2 mice in each group). ${ }^{*} p<0.05$. (D) Representative microscopic images from hot spot areas of mouse lung immunostained for CD31 (original magnification, $400 \times$ ) with quantification of microvessel number per high-power field (HPF). The data are expressed as the mean \pm SEM ( $\mathrm{n}=15$ areas from 2 mice in each group). ${ }^{* * *} p<0.001$. (E) Quantification of the number of progeny per litter of wild-type and $D R G 2^{-/-}$. The data are expressed as mean $\pm \mathrm{SD}$. ( $\mathrm{n}=26$ for wild-type and 45 for $D R G 2^{-/-}$).

\subsection{DRG2 Deficiency Inhibits Angiogenic Functions of Endothelial Cells}

The endothelial cell lining of blood vessels is a critical component of many physiological functions [32]. To determine the effect of DRG2 deficiency on the angiogenic function of endothelial cells, three studies were conducted. First, we investigated the influence of 
DRG2 deficiency on the formation of capillary-like tubes in primary mouse lung endothelial cells (mLECs) after the addition of recombinant VEGF-A. VEGF-A was found to stimulate tube formation in both wild-type and DRG2 $2^{-/-}$mLECs (Figure 2A,B). However, the total tube lengths in DRG2-/- mLECs treated with $100 \mathrm{ng} / \mathrm{mL}$ VEGF-A were significantly decreased compared with those of the wild-type (Figure 2A,B), demonstrating that DRG2 deficiency impaired endothelial cell tube formation in vitro.

A

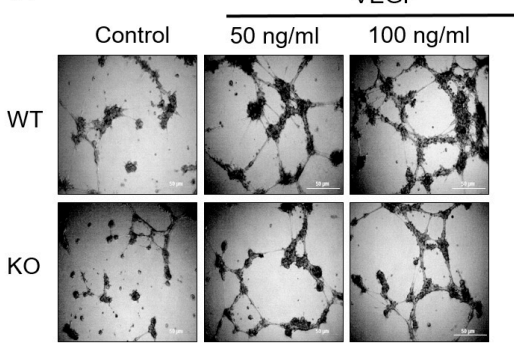

B

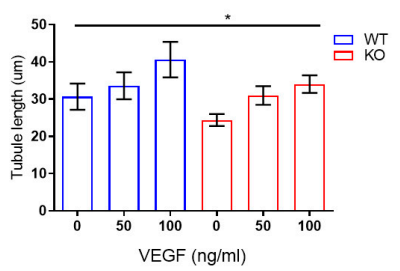

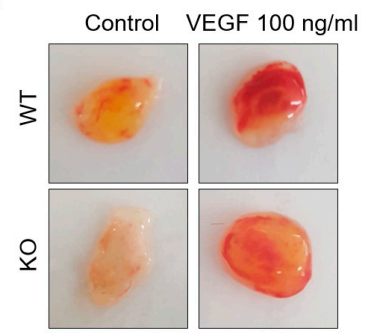

$\mathrm{D}$

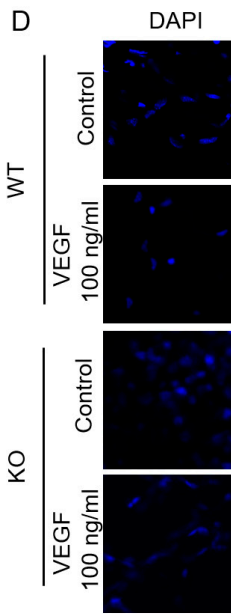

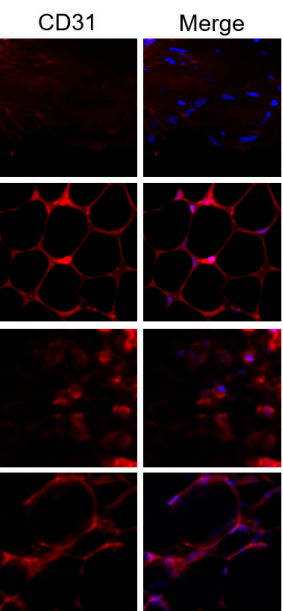

E

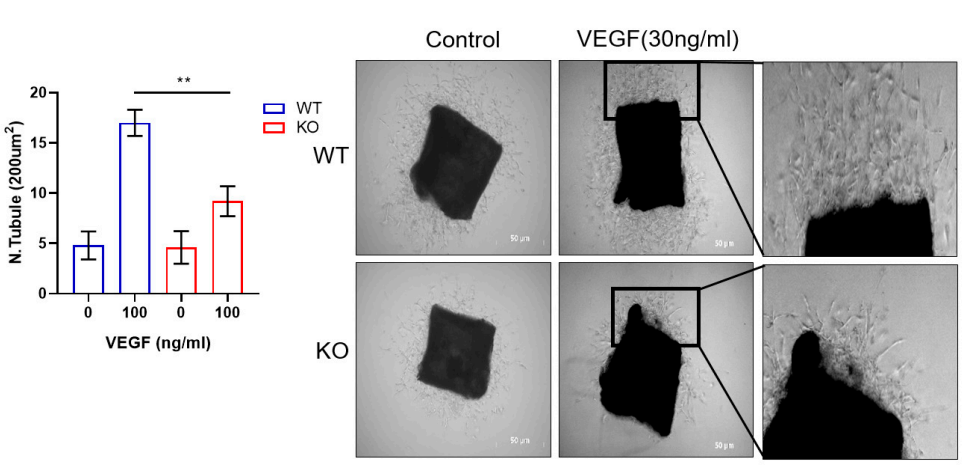

$\mathrm{F}$

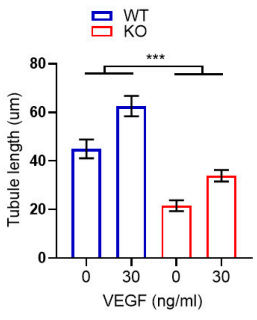

Figure 2. Effects of $D R G 2$ deficiency on the angiogenic function of endothelial cells. $(\mathbf{A}, \mathbf{B})$ Effects of $D R G 2$ deficiency on tube formation in mouse lung endothelial cells (mLECs). The mLECs from WT and $D R G 2^{-/-}(\mathrm{KO})$ mice were seeded on Matrigel and monitored for tube formation after incubation for $24 \mathrm{~h}$ in the absence or presence of recombinant VEGF-A (50 or $100 \mathrm{ng} / \mathrm{mL}$ ). (A) Representative images of tube formation by mLEC cells stimulated with recombinant VEGF-A or the supernatant of melanoma cells. Scale bar $=50 \mu \mathrm{m}$. (B) Quantification of the length of tubes. Data represent the tube length from four randomly chosen fields of three independent experiments and mean $\pm \mathrm{SD}$. Two-way ANOVA, ${ }^{*} p<0.05$. (C,D) Effect of $D R G 2$ deficiency on neovascularization in the Matrigel plug. Wild-type and $D R G 2^{-/-}(\mathrm{KO})$ mice were s.c. injected with Matrigel plugs containing 100 $\mathrm{ng} / \mathrm{mL}$ VEGF, and blood vessels developed over 10 days. (C) Representative macroscopic images of Matrigel plugs from wild-type and $D R G 2^{-/-}$mice. (D) Representative images of anti-CD31 stained paraffin sections of Matrigel plugs from wild-type and $D R G 2^{-/}$mice CD31 (original magnification, $400 \times$ ) with quantification of CD31-positive vessels. A total of 3 fields from individual plugs of 3 animals per group was counted. The data are expressed as the mean $\pm \operatorname{SD}(n=9$ in each group). ** $p<0.005$. (E,F) Effect of DRG2 deficiency on endothelial cell sprouting in an aorta ring assay. Aortic rings obtained from wild-type and $D R G 2^{-/-}$mice were incubated for 7 days in the absence or presence of VEGF-A ( $30 \mathrm{ng} / \mathrm{mL}$ ). (E) Representative areas of the aortic rings are marked with boxes and enlarged correspondingly on the right side of each panel (original magnification, $100 \times$ ). (F) The graph represents the overall length of endothelial cell sprouts and the overall number of endothelial cell sprouts emerging from the aortic ring. The data are expressed as the mean $\pm S D(n=6$ aortic rings from two mice in each group). ${ }^{* * *} p<0.001$. 
Second, we assessed the effect of DRG2 deficiency on the angiogenic potential of mice, by in vivo Matrigel plug assay. Matrigel was subcutaneously injected into wild-type and $D R G 2^{-/-}$mice, and the implants were removed after 10 days to evaluate neovascularization. To allow efficient vascularization, angiogenic growth factor VEGF-A was suspended in the Matrigel before injection. Controls did not contain the VEGF-A supplement. A redcolored plug filled with red blood cells (RBCs) indicated the formation of new blood vessels inside the Matrigel. As shown in Figure 2C, the red color of plugs from $D R G 2^{-/-}$mice was much lighter than that from wild-type mice, suggesting the formation of fewer blood vessels. Matrigel plugs were harvested, sectioned, and analyzed for capillary by immunohistochemical (IHC) staining with anti-CD31 antibody. The overall vascular densities in the Matrigel plugs are shown in Figure 2D. DRG2 ${ }^{-/-}$mice exhibited lower neovascularization of the Matrigel implants upon angiogenic challenge with VEGF compared with wild-type mice (Figure 2D). Without the addition of VEGF-A (i.e., controls), the implants remained largely avascular. In addition, whereas the vascular endothelial structures detected in the plugs from wild-type mice were orderly, the blood vessels in the plugs from DRG2-/mice were poorly organized (Figure 2D).

Third, we prepared aortas from wild-type and $D R G 2^{-/-}$mice and determined the effect of DRG2 deficiency on endothelial cell outgrowth by performing aortic ring assays. The aortic ring assays analyzed the newly formed endothelial cell network protruding from aortic explants. A comparison of the assay can be found in Figure 2E. Endothelial cell tubes protruding from aortic explants of $D R G 2^{-/-}$mice formed a less complex endothelial network compared with the rather dense network emerging from explants of wild-type mice. In addition, the overall length of the endothelial cell sprouts emerging from the aortic explants of $D R G 2^{-/-}$mice was significantly lower than that of wild-type mice (Figure $2 \mathrm{~F}$ ). Collectively, these results suggest that DRG2 deficiency leads to defective angiogenesis.

\subsection{DRG2 Deficiency Decreases Proliferation and Enhances Senescence of Endothelial Cells}

Cell proliferation is essential for endothelial cells to adequately perform their angiogenic functions; therefore, the senescence of endothelial cells impairs angiogenesis [33]. The defects in the angiogenic function of $D R G 2^{-/-}$endothelial cells prompted us to investigate whether $D R G 2$ deficiency affects the proliferation of endothelial cells. We first determined the effect of DRG2 deficiency on mLECs proliferation using an MTS assay. The $D R G 2^{-/-}$mLECs demonstrated decreased proliferation compared with that of DRG2 $2^{+/+}$ mLECs (Figure 3A). A Ki67 staining study further supported the decreased proliferation in DRG2-I- mLECs (Figure 3B). Since apoptosis can contribute to the numbers of endothelial cells, we examined apoptotic activity in mLECs by Annexin- $V$ staining. However, there was no significant difference in apoptosis between wild-type and DRG2 ${ }^{-/-}$mLECs (Figure 3C). We next asked whether DRG2 deficiency affects the senescence of endothelial cells. Senescent cells have increased activity of senescence-associated $\beta$-gal (SA- $\beta$-gal) [34], a well-defined biomarker for cellular senescence. We evaluated SA- $\beta$-gal activity in wildtype and $D R G 2^{-/-}$mLECs. The number of SA- $\beta$-gal-stained cells was significantly increased in DRG2 $2^{-/-}$mLECs compared with that of DRG2 $2^{+/+}$mLECs (Figure 3D). One of the defining features of senescent cells is cell cycle arrest in G1 [7]. We examined whether $D R G 2$ deficiency induces cell cycle arrest in mLECs. Cell cycle distribution analysis revealed an increased accumulation of G1 phase cells in DRG2 ${ }^{-/-}$mLECs (Figure 3E). To determine whether $D R G 2^{-/-}$mice show senescence phenotype, we collected uteruses from wild-type and $D R G 2^{-/-}$mice and stained them for SA- $\beta$-gal activity. We could detect stronger SA- $\beta$-gal activity in DRG2 $2^{-/-}$uteruses than wild-type uteruses (Figure 3F). These results indicate that $D R G 2$ deficiency decreases proliferation and increases the senescence of endothelial cells. 
A

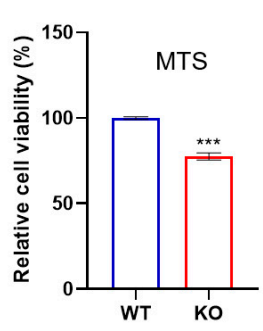

B

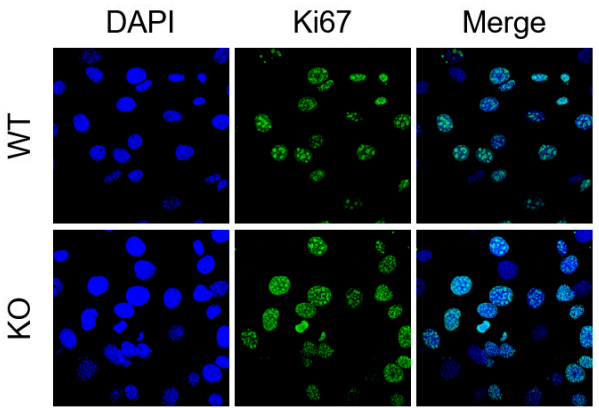

C

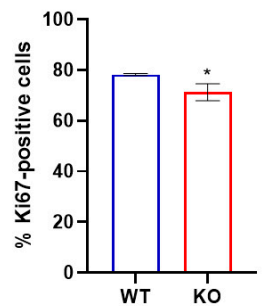

D

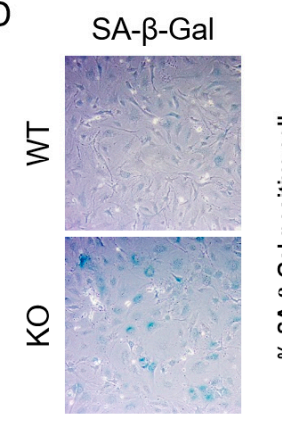

$E$

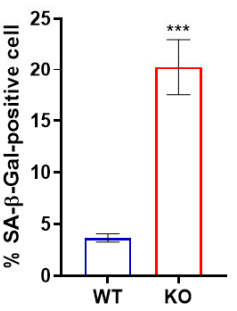

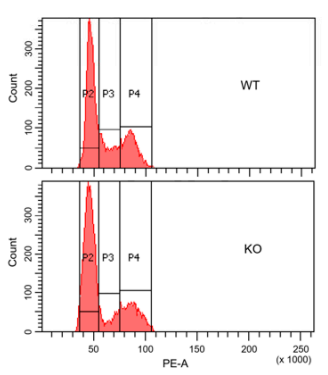

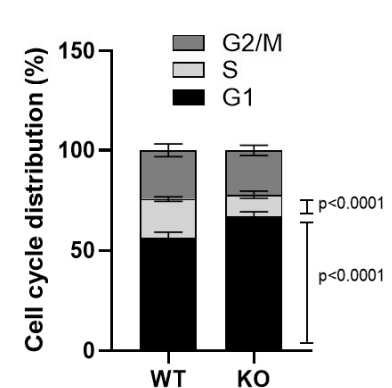

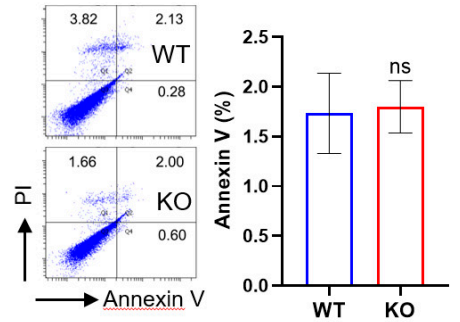

$\mathrm{F}$

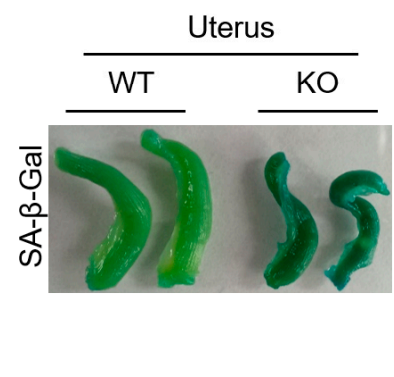

Figure 3. Effects of DRG2 deficiency on the proliferation, apoptosis, and senescence of endothelial cells. Lung endothelial cells (mLECs) derived from wild-type and DRG2-/- mice were cultivated under normal conditions as described in the Section 4 without any treatment. The mLECs were analyzed by (A) MTS assay ( $\mathrm{n}=3$ independent experiments in each group) and (B) Ki67 staining for cell proliferation ( $n=40$ cells per 3 independent experiments in each group), (C) Annexin-V staining and FACS analysis for apoptosis ( $\mathrm{n}=3$ independent experiments in each group), (D) senescence-associated $\beta$-gal (SA- $\beta$-gal) staining for cellular senescence $(n=120$ cells per 3 independent experiments in each group), and (E) FACS analysis for cell cycle arrest ( $\mathrm{n}=10$ independent experiments). (F) Detection of SA- $\beta$-gal activity in uteruses from wild-type and $D R G 2^{-/-}$mice. Images in (B,D) are representative (Original magnification $600 \times$ and $200 \times$, respectively) of Ki67-stained cells and SA- $\beta$-gal-stained cells, respectively. The data are expressed as the mean $\pm \mathrm{SD} .{ }^{*} p<0.05 ;{ }^{* * *} p<0.001$. ns, not significant.

\subsection{DRG2 Deficiency Enhances DNA Damage and Senescence Induced by Oxidative Stress}

Oxidative stress causes DNA damage [35] and cellular senescence [13,36]. Since $\mathrm{H}_{2} \mathrm{O}_{2}$ is a major ROS generated during oxidative stress [37,38], we examined whether DRG2 deficiency affects the senescence response to oxidative stress using $\mathrm{H}_{2} \mathrm{O}_{2} \cdot \mathrm{H}_{2} \mathrm{O}_{2}$ significantly increased the number of SA- $\beta$-gal-stained cells in both wild-type and DRG2 $2^{-/-}$ mLECs (Figure 4A). However, after $\mathrm{H}_{2} \mathrm{O}_{2}$ treatment, the number of SA- $\beta$-gal-stained cells in DRG2- I- mLECs was much higher than that of wild-type mLECs (Figure 4A). Accumulated DNA damage activates p53, leading to cellular senescence [39]. An increase in phosphorylated histone $\mathrm{H} 2 \mathrm{AX}(\gamma \mathrm{H} 2 \mathrm{AX})$ was considered as a biomarker of cellular senescence [40]. We examined the effect of DRG2 deficiency on oxidative stress-induced DNA damage by analyzing the levels of phosphorylated p53 and $\gamma \mathrm{H} 2 \mathrm{AX}$. After $\mathrm{H}_{2} \mathrm{O}_{2}$ treatment, $D R G 2^{-/-}$mLECs showed a significantly higher level of total and phosphorylated p53 than wild-type mLECs did (Figure 4B). Consistently, the level of $\gamma \mathrm{H} 2 \mathrm{AX}$ induced by $\mathrm{H}_{2} \mathrm{O}_{2}$ was higher in DRG2 $2^{-1}$ mLECs than in WT mLECs (Figure 4C). Even in the absence of $\mathrm{H}_{2} \mathrm{O}_{2}$ treatment, $D R G 2^{-/-}$mLECs showed higher levels of phosphorylated p53 and $\gamma \mathrm{H} 2 \mathrm{AX}$ than WT mLECs did (Figure 4B,C). We also treated mLECs with DNA damaging agents doxorubicin and etoposide and analyzed the expression level of phosphorylated p53. Consistent with $\mathrm{H}_{2} \mathrm{O}_{2}, D R G 2^{-/-}$mLECs showed a significantly higher level of phosphorylated p53 than wild-type mLECs after treatment with doxorubicin (Figure 4D) and etoposide (Figure 4E). In 
addition, doxorubicin and etoposide induced a higher level of p21 in DRG2-/- mLECs than wild-type mLECs (Figure $4 \mathrm{D}, \mathrm{E}$ ). These results suggest that $D R G 2$ deficiency increases the levels of p21, $\gamma \mathrm{H} 2 \mathrm{AX}$, and phosphorylated p53 induced by oxidative stress in mLECs, which means that $D R G 2$ may play a role in suppressing their levels in mLECs. Senescent cells are characterized by production of inflammatory cytokines, immune modulators, growth factors, and proteases, which comprise the senescence-associated secretory phenotype (SASP) [41]. To determine if DRG2 deficiency would also induce components of the SASP, levels of IL-6, CXCL10, and IFN- $\beta 1$ in wild-type and DRG2 ${ }^{-1-}$ mLECs were measured after etoposide treatment using $\mathrm{qPCR}$. In the absence of etoposide treatment, both wild-type and DRG2-/- mLECs expressed very low levels of these cytokines and $D R G 2^{-/-}$mLECs expressed higher level of only IL-6 than wild-type mLECs did. After etoposide treatment, expression levels of three cytokines were enhanced in both wild-type and $D R G 2^{-/-}$mLECs and DRG2 ${ }^{-/-}$mLECs expressed significantly higher levels of these cytokines than wild-type mLECs did (Figure 4F). These data suggest that DNA damage and cellular senescence are enhanced by oxidative stress in DRG2 ${ }^{-/-}$mLECs.
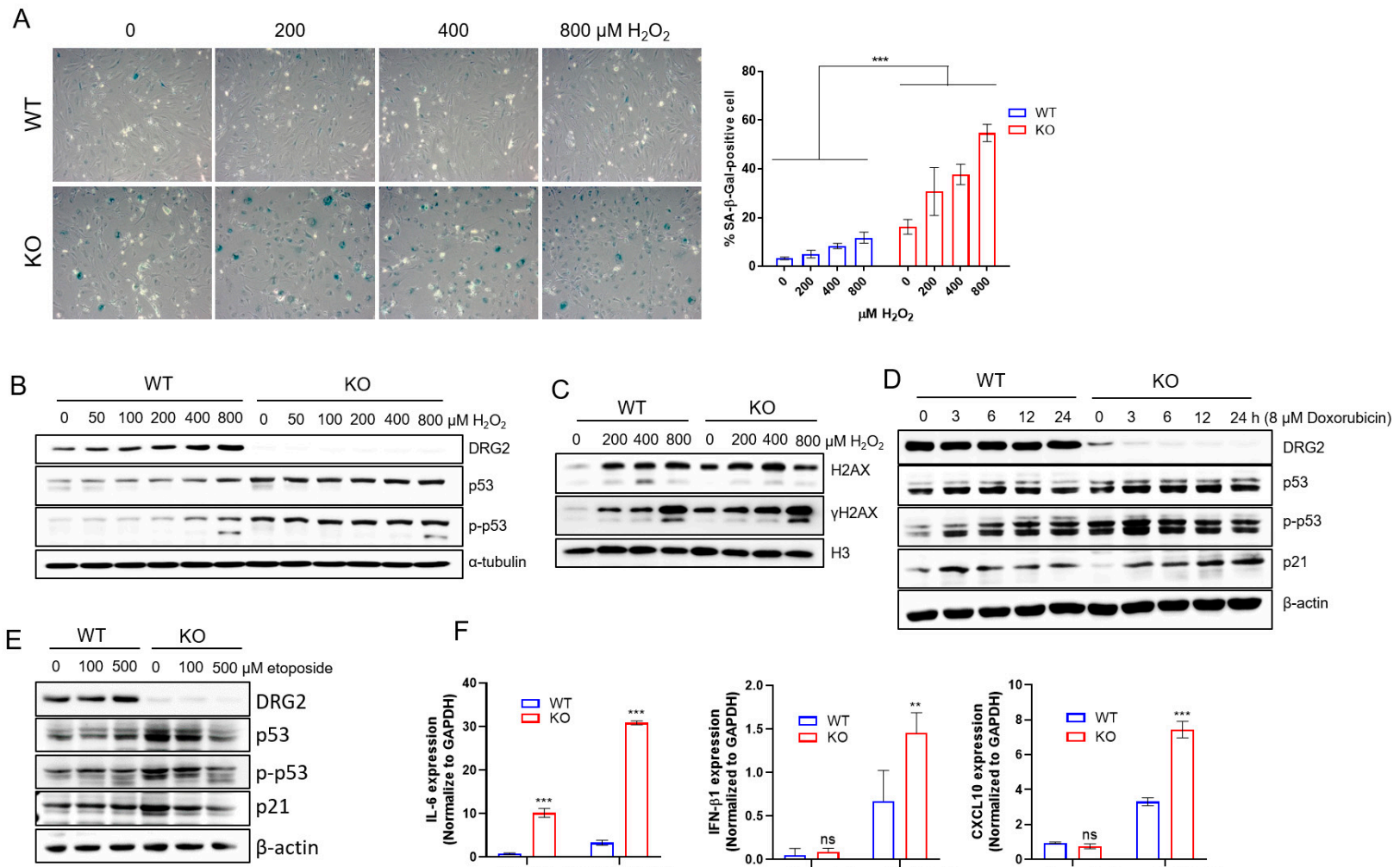

$\mathrm{F}$
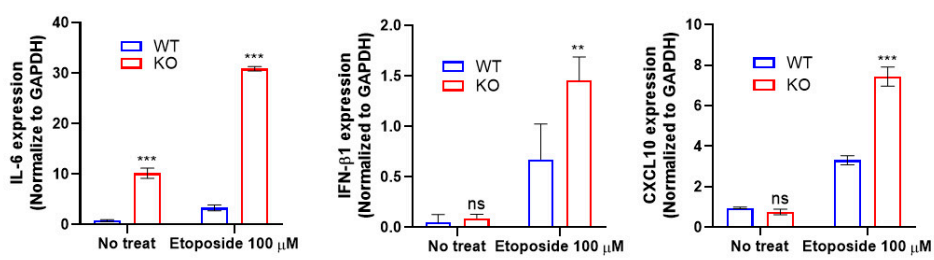

Figure 4. Enhanced oxidative stress-induced DNA damage and senescence in DRG2 deficient endothelial cells. (A-C) mLECs from wild-type and $D R G 2^{-/-}$mice were exposed to $\mathrm{H}_{2} \mathrm{O}_{2}$ at the indicated concentrations for $6 \mathrm{~h}$. (A) Representative images of SA- $\beta$-gal-stained cells (original magnification $200 \times$ ) with quantification of SA- $\beta$-gal-positive cells. The data are expressed as the mean $\pm \mathrm{SD}$ ( $\mathrm{n}=5$ in each group). ${ }^{* * *} p<0.001$. (B,C) Cells were analyzed by Western blot assay for the levels of (B) total and phosphorylated p53, and (C) $\gamma \mathrm{H} 2 \mathrm{AX}$. (D) mLECs from wild-type and $D R G 2^{-/-}$mice were treated with $8 \mu \mathrm{M}$ doxorubicin for the indicated time and analyzed by Western blot assay for the levels of total and phosphorylated p53, and p21. (E) mLECs from wild-type and $D R G 2^{-/}$mice were treated with indicated concentration of etoposide for $24 \mathrm{~h}$ and analyzed by Western blot assay for the levels of total and phosphorylated p53, and p21. All Western blot data were representative ones of more than two experiments. (F) mLECs from wild-type and DRG2-/mice were incubated for $6 \mathrm{~h}$ in the absence or presence of $100 \mu \mathrm{M}$ etoposide and analyzed by qPCR for levels of $I L-6, I F N-\beta 1$ and CXCL10. The data are expressed as the mean \pm SD ( $\mathrm{n}=3$ in each group). ** $p<0.005,{ }^{* * *} p<0.001$. 


\subsection{DRG2 Deficiency Affect the Expression of Antioxidant Genes}

Previously, we reported that $D R G 2$ deficiency induces mitochondrial dysfunction and increases intracellular ROS in cancer cells [28]. Consistently, DRG2 ${ }^{-/-}$mLECs showed a decrease in mitochondrial membrane potential compared with wild-type mLECs (Figure 5A). We also confirmed an increase in intracellular ROS level before and after doxorubicin treatment in DRG2 $2^{-/-}$mLECs compared to wild-type mLECs (Figure 5B). Since oxidative stress is one of the major factors causing the onset of senescence [13], we used ROS scavenger N-acetylcysteine (NAC) to test whether increased levels of ROS lead to increased senescence in DRG2 $2^{-/-}$mLECs. NAC treatment effectively reduced the number of SA$\beta$-gal-stained cells in both wild-type and DRG2 ${ }^{-1-}$ mLECs (Figure 5C), indicating that increased ROS is one of the major causative factors for enhanced senescence in DRG2-/mLECs. To combat oxidative stress, cells produce several antioxidant enzymes [42]. We next examined whether DRG2 deficiency affects the expression of the antioxidant genes, superoxide dismutase 1 (SOD1) and SOD2. The expression levels of SOD1 (Figure 5D) and SOD2 (Figure 5E) were significantly lower in DRG2 ${ }^{-/-}$mLECs both before and after $\mathrm{H}_{2} \mathrm{O}_{2}$ treatment than in wild-type mLECs, implicating the reduced expression of antioxidant genes to play a role in increased ROS level and senescence in DRG2 $2^{-/-}$mLECs.

A

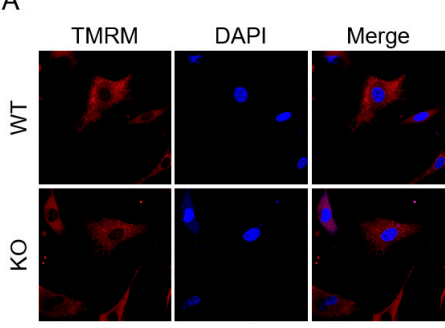

D

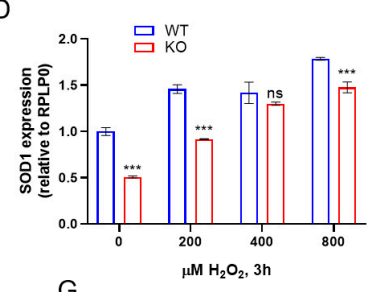

G

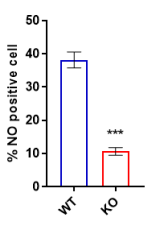

B

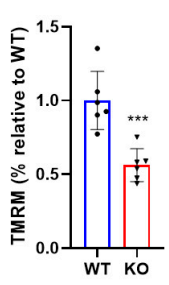

E

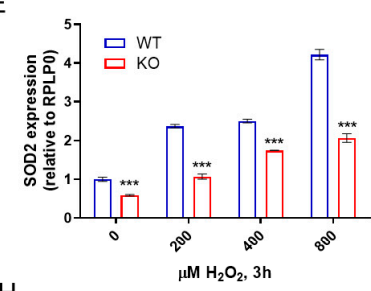

$\mathrm{H}$

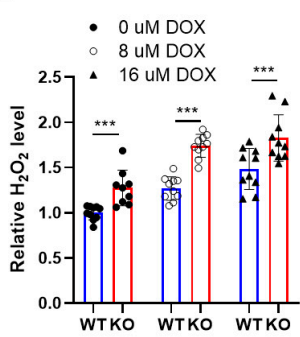

C

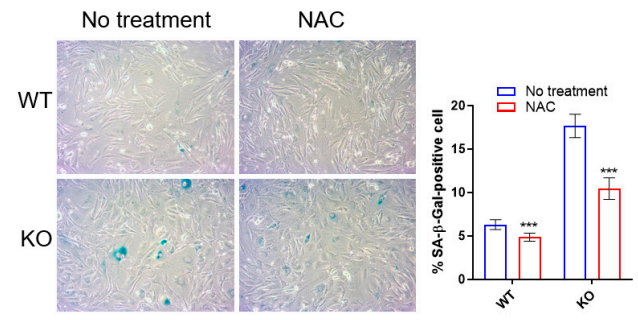

$\mathrm{F}$
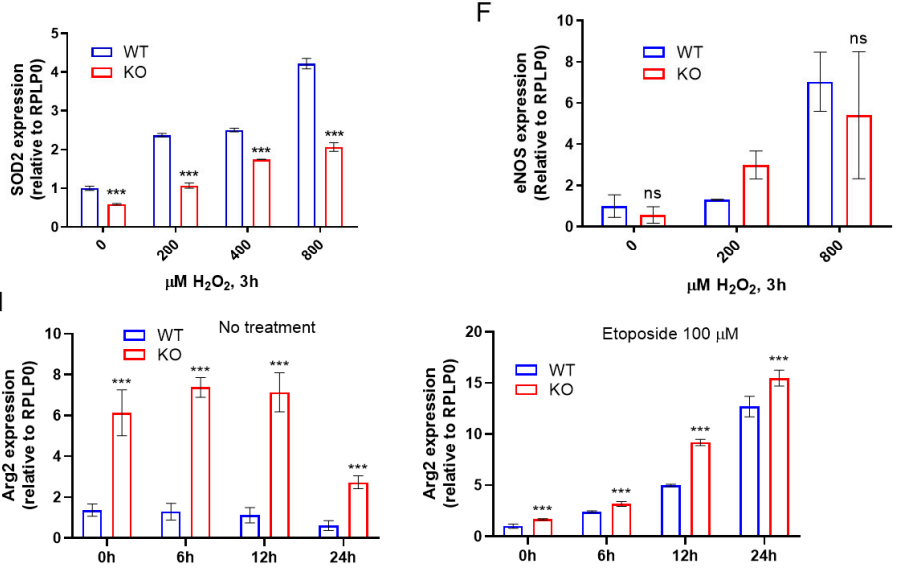

Figure 5. Effect of DRG2 deficiency on the production of reactive oxygen species (ROS) and NO in endothelial cells. (A) representative images of wild-type and DRG2 $2^{-/-}$mLECs stained with TMRM for mitochondrial membrane potential and DAPI for nucleus (original magnification $600 \times$ ). The data are expressed as the mean $\pm \mathrm{SD}$ ( $\mathrm{n}=6$ in each group). ${ }^{* *} p<0.001$. (B) mLECs from wild-type and $D R G 2^{-1-}$ mice were exposed to doxorubicin at the indicated concentrations for $6 \mathrm{~h}$ and were analyzed for $\mathrm{H}_{2} \mathrm{O}_{2}$ levels as described in the Section 4. The level obtained from untreated wild-type mLECs was set to 1 . The data are expressed as the mean $\pm \mathrm{SD}\left(\mathrm{n}=10\right.$ in each group). ${ }^{* *} p<0.001$. (C) Representative images of SA- $\beta$-gal-stained cells (original magnification $200 \times$ ) with quantification of SA- $\beta$-gal-positive cells. mLECs from wild-type and $D R G 2^{-/-}$mice were exposed to $5 \mathrm{mM}$ NAC for $6 \mathrm{~h}$ and were analyzed for SA- $\beta$-gal-positive cells. The data are expressed as the mean $\pm \mathrm{SD}$ ( $\mathrm{n}=3$ in each group). ${ }^{* *} p<0.001$. (D-F) Effect of $D R G 2$ deficiency on the $\mathrm{H}_{2} \mathrm{O}_{2}$-induced expression of anti-oxidant genes in endothelial cells. mLECs from wild-type and $D R G 2^{-/-}$mice were exposed to $\mathrm{H}_{2} \mathrm{O}_{2}$ at the indicated concentrations for $6 \mathrm{~h}$ and analyzed by qPCR for the levels of SOD1, SOD2, and 
eNOS. The data are expressed as the mean $\pm \mathrm{SD}\left(\mathrm{n}=3\right.$ in each group). $\mathrm{ns}$, not significant. ${ }^{* * *} p<0.001$. (G) Effect of DRG2 deficiency on the production of nitric oxide (NO) in endothelial cells. mLECs from wild-type and $D R G 2^{-/}$mice cultivated under normal condition without any treatment were analyzed for NO production as described in the Section 4 . The data are expressed as the mean \pm SD ( $\mathrm{n}=3$ in each group). ${ }^{* *} p<0.001$. (H) mLECs from wild-type and DRG2-/- mice were incubated in the absence or presence of $100 \mu \mathrm{M}$ etoposide for the indicated time and analyzed by qPCR for level of Arginase 2 (Arg2). The data are expressed as the mean $\pm \mathrm{SD}\left(\mathrm{n}=3\right.$ in each group). ${ }^{* *} p<0.001$.

\subsection{DRG2 Deficiency Decreases eNOS Expression and NO Production in Endothelial Cells}

Since eNOS-derived NO functions are an anti-senescent factor in ECs [43], we examined the effect of DRG2 deficiency on the eNOS/NO pathway. There was no significant difference in the expression of eNOS between DRG2 $2^{-/-}$mLECs and wild-type mLECs (Figure 5F). However, NO production was significantly decreased in DRG2-/- mLECs compared to wild-type mLECs (Figure 5G). eNOS produces NO by catalyzing L-arginine to L-citrulline. However, when the substrate L-arginine is depleted by the enzyme arginase (Arg), eNOS produces ROS instead of NO, which was referred to as eNOS coupling. The increased ROS generation leads to endothelial dysfunction $[44,45]$. We next examined whether DRG2 deficiency affects the expression of Arg2 in endothelial cells. The expression level of Arg2 was significantly higher in DRG2-/- mLECs both before and after etoposide treatment than in wild-type mLECs (Figure 5H). Collectively, these results suggest that the induction of senescence by DRG2 deficiency in mLECs is associated with modulated expression of $A r g 2$, which affects the intracellular levels of $\mathrm{NO}$ and ROS.

\section{Discussion}

Our previous data suggested that DRG2 in cancer cells is involved in tumor angiogenesis [30]. However, the role of $D R G 2$ in endothelial cells remains to be explored. In the present study, we investigated the role of DRG2 in endothelial cell functions, especially angiogenic functions, using $D R G 2^{-/-}$mice. Here, we provide evidence that $D R G 2$ is involved in angiogenesis and vascular remodeling, in that (a) $D R G 2^{-/-}$mice showed decreased blood flow in the brain. Since regulation of CBF is controlled by cerebral endothelium [46], reduction in the CBF in $D R G 2^{-/-}$mice implicates the role of DRG2 in endothelium function; (b) DRG2 deficiency reduced pulmonary blood vessel density. The intensity of CD31 staining in the lung of $D R G 2^{-/-}$mice was significantly reduced compared to that of wild-type mice; (c) DRG2 deficiency inhibited neovascularization of subcutaneous Matrigel implants. When the Matrigel plugs containing the angiogenic growth factor VEGF were transplanted subcutaneously, DRG2-/- mice exhibited low and poorly organized neovascularization of the Matrigel implant compared to wild-type mice. These results suggest that DRG2 deficiency leads to a defect in angiogenesis; (d) DRG2 deficiency impaired microvessel outgrowth in an ex vivo aorta ring assay. In aortic ring assays, the branching of newly formed sprouts was significantly reduced in $D R G 2^{-/-}$aorta explants compared to WT aorta explants; and (e) DRG2 deficiency reduced the in vitro tube-forming capability of endothelial cells. When treated with VEGF, lung endothelial cells from $D R G 2^{-/-}$mice showed a decrease in the formation of tube-like structures compared to those from wildtype mice. Collectively, our results suggest that DRG2 deficiency induces dysfunction of endothelial cells, especially in angiogenesis.

Cell proliferation is essential for endothelial cells to adequately perform their angiogenic functions and senescence of endothelial cells can contribute to endothelial dysfunction and impair angiogenesis $[33,47]$. We reported previously that DRG2 deficiency increases intracellular ROS levels in cancer cells [28]. Consistently, in this experiment, we also found that DRG2-/- endothelial cells produce enhanced levels of ROS compared to wild-type endothelial cells. ROS can induce DNA damage [35] and cellular senescence [13,36]. In the present work, we found that DRG2 deficiency enhanced SA- $\beta$-gal activity, a biomarker for senescence [34], in endothelial cells. The increase in SA- $\beta$-gal activity in DRG2-/endothelial cells was attenuated by concomitant application of NAC, a ROS scavenger, 
indicating that increased levels of ROS led to increased senescence in DRG2-/- endothelial cells. A characteristic feature of cellular senescence is cell cycle arrest in the G1 phase [7] and the SASP [41] involving increased expression of inflammatory molecules [48]. In the present work, we also found that $D R G 2^{-/-}$endothelial cells expressed higher levels of inflammatory molecules such as IL-6, CXCL-10, and IFN- $\beta 1$ than did wild-type endothelial cells, providing further evidence supporting the induction of senescence in $D R G 2^{-/-}$endothelial cells. Excessive ROS production can induce DNA damage $[36,49,50]$ and activate the p53-p21 WAF1/CIP1 senescence pathway [51-53]. Consistently, we observed cell cycle arrest in the G1 phase (Di Leonardo et al., 1994) and increased levels of DNA damage marker $\gamma \mathrm{H} 2 \mathrm{AX}$ [40], p21 and phosphorylated p53 in DRG2 ${ }^{-/-}$endothelial cells compared to wild-type endothelial cells. Collectively, our results indicate that DRG2 deficiency increases intracellular ROS, which leads to DNA damage and senescence in endothelial cells. The proliferation of endothelial cells is one of the key steps of the VEGF-mediated angiogenic process [54]. DRG2 deficiency-induced senescence may limit the capacity of VEGF to promote angiogenesis in $D R G 2^{-/-}$endothelial cells.

How does DRG2 deficiency increase ROS in endothelial cells? eNOS plays a key role in increasing vascular ROS production [55]. It is the predominant NOS form in the vasculature and normally oxidizes its substrate L-arginine to produce the vasoprotectant molecule NO [56]. However, under limited-L-arginine, eNOS produces ROS instead of $\mathrm{NO}$, referred to as eNOS uncoupling [57,58]. Endothelial cells express arginases that can compete with eNOS for L-arginine and, if highly expressed, "starve" eNOS. Arginase exists in two isoforms; in human endothelial cells, Arg2 seems to be the predominant isozyme [15,59]. Upregulation of $A r g 2$ was found to decrease NO generation and increase ROS production via eNOS uncoupling [45]. In the present work, we found that, even though DRG2 deficiency did not affect eNOS expression, it downregulated the intracellular NO level in endothelial cells. When we analyzed the expression level of Arg2, we found that $D R G 2^{-/-}$endothelial cells produced a higher level of Arg2 than did wild-type endothelial cells, suggesting that DRG2-/- endothelial cells produce ROS via eNOS uncoupling. Although our study did not determine other sources of ROS and the effect of Arg2 inhibition on ROS production, our results suggest that eNOS uncoupling is an important contributor to ROS production and senescence induction in DRG2 $2^{-/-}$endothelial cells.

In summary, we demonstrated that DRG2 deficiency can induce endothelial dysfunction, such as reduced blood flow and a decrease in angiogenesis in vivo, ex vivo, and in vitro. DRG2 deficiency increased ROS production in endothelial cells through eNOS uncoupling and induced endothelial senescence. The enhanced endothelial senescence can contribute to the dysfunction found in the DRG2-deficient endothelium. Even though we did not determine whether there was an enhanced frequency of vascular diseases in $D R G 2^{-/-}$mice, DRG2 deficiency can increase ROS and, thus, endothelial dysfunction and lead to vascular diseases. Further studies are required to explore in more detail the roles of DRG2 in DNA damage, endothelial senescence, and vascular diseases.

\section{Materials and Methods}

\subsection{Cell Culture}

Mouse lung endothelial cells (mLECs) were isolated by methods as previously described [30]. Briefly, cell suspensions were prepared by digesting mouse lungs in collagenase and incubated with anti-CD31 monoclonal antibody for $30 \mathrm{~min}$ at $4{ }^{\circ} \mathrm{C}$. Cells were pulled down using magnetic beads coated with sheep anti-IgG. After washing four times, cells were digested with trypsin-EDTA to detach the beads. Cells were cultured in Dulbecco's Modified Eagle Medium (DMEM) (Thermo Fisher Scientific, Waltham, MA, USA) supplemented with 15\% fetal bovine serum (FBS; Thermo Fisher Scientific, Waltham, MA, USA), heparin (100 $\mu \mathrm{g} / \mathrm{mL}$ ) (Sigma, St. Louis, MO, USA), $100 \mathrm{U} / \mathrm{mL}$ penicillin, and $100 \mu \mathrm{g} / \mathrm{mL}$ streptomycin (Thermo Fisher Scientific) in a 2\% gelatin (Sigma)-coated plate at $37^{\circ} \mathrm{C}$ and $5 \% \mathrm{CO}_{2}$. 


\subsection{Mice and Animal Research Ethics}

$D R G 2^{-/-}$mice were as described previously [26]. Mice were bred in the animal facility at the University of Ulsan, and offspring were born and housed in the same room under specific pathogen-free conditions. All animal procedures were approved by the Institutional Animal Care and Use Committee of the Meta-inflammation Research Center (permit number JWP-21-020). All surgery was performed under sodium pentobarbital anesthesia, and all efforts were made to minimize suffering.

\subsection{Cortical Cerebral Blood Flow Measurement}

Real-time two-dimensional cerebral blood flow (CBF) was monitored using a laser speckle contrast imager (PeriCam PSI HR System, Perimed, Sweden). Mice were anesthetized and placed in the prone position and the skull was exposed through a cut in the skin at the parietal midline. A scanning camera was placed above the head at a working distance of $10 \mathrm{~cm}$ from the skull surface and illuminated with a laser diode $(785 \mathrm{~nm})$ to penetrate the brain. To evaluate CBF changes, the region-of-interest (ROI) included the cortical area supplied by the middle cerebral artery.

\subsection{In Vivo Matrigel Plug Assays}

This assay was performed by methods described previously with modification [60]. Mice were injected subcutaneously with $0.5 \mathrm{~mL}$ Matrigel (BD Biosciences, San Jose, Santa Clara, CA, USA) containing 100 ng recombinant murine VEGF (R\&D Systems, Minneapolis, MN, USA). Controls did not contain VEGF. After 10 days, the mice were sacrificed and plugs were harvested from underneath the skin. The plugs were fixed, embedded, and sectioned. To visualize capillaries, samples were immunohistochemically stained with anti-CD31 antibody (sc-376764, Santa Cruz, Santa Cruz, CA, USA).

\subsection{Aortic Ring Assay}

Aortas were prepared from wild-type and DRG2 KO mice, and aortic ring assays were performed as described previously with modification [61]. Briefly, $0.5 \mathrm{~mm}$ mouse aortic rings were embedded in 3-dimensional growth factor reduced Matrigel (354230, Corning, Corning, NY, USA). Opti-MEM (31985062, Thermo Fisher Scientific) containing $30 \mathrm{ng} / \mathrm{mL}$ VEGF (450-32, PeproTech, Cranbury, NJ, USA) was added to induce vessel outgrowth. Sprouting vessels were counted at day 7 after incubation and photographed using a Nikon Eclipse TS 100 (Nikon, Tokyo, Japan) phase-contrast microscope.

\subsection{Immunohistochemistry and Quantification of Lung Angiogenesis}

Immunohistochemical analysis was performed on $4-\mu$ m-thick tissue sections cut from formalin-fixed paraffin-embedded surgical specimens. The sections were stained with hematoxylin and eosin (HE) or with anti-CD31 antibody (1:200 dilution; DAKO, Glostrup, Denmark) using a VENTANA BenchMark XT automated staining device (Ventana Medical System, Tucson, AZ, USA), according to the manufacturer's instructions. The Vessel area was determined by CD31 positive staining normalized to the total area fraction. The number of microvessels was counted as described previously [62]. Briefly, the most vascularized areas were selected and counted in a $\times 400$ field. Any single or cluster of endothelial cells that were separated clearly from adjacent microvessels was considered as one countable microvessel. The average counts from the three most vascularized areas were recorded in each case to measure the degree of angiogenesis.

\subsection{Endothelial Tube Formation In Vitro Assays}

The in vitro angiogenic activity of mLECs derived from wild-type and DRG2 KO mice was determined by Matrigel tube formation assay. Matrigel (354230, Corning) was added to each well (50 $\mu \mathrm{L}$ per well) of a 96-well plate and allowed to solidify at $37^{\circ} \mathrm{C}$ for $30 \mathrm{~min}$. Then, $1 \times 10^{4}$ mLEC cells in $100 \mu \mathrm{L}$ of DMEM were placed in each well and incubated at $37^{\circ} \mathrm{C}$ for $6 \mathrm{~h}$ with or without addition of $100 \mathrm{ng} / \mathrm{mL}$ of mouse recombinant VEGF 
(BD Biosciences). The ability of the cells to form endothelial tubes was evaluated under phase-contrast microscopy using a Nikon Eclipse TS100 inverted microscope equipped with a Nikon DXM-1200 digital camera (Nikon, Tokyo, Japan). Images of tube morphology were obtained in five random microscopic fields per sample at $\times 40$ magnification, and the cumulative tube lengths were measured by Image-Pro Plus software (Media Cybernetics, Rockville, MD, USA).

\subsection{Colony-Forming Assay}

Clonogenic assays were carried out as described previously [63]. Briefly, 1600 cells were seeded into a $60 \mathrm{~mm}$ plate and incubated for $2 \mathrm{~h}$ at $37^{\circ} \mathrm{C}$. They were then incubated for a further 2 weeks with or without addition of $8 \mu \mathrm{M}$ or $16 \mu \mathrm{M}$ doxorubicin (Sigma). Cells were fixed with $3.7 \%$ formalin for $10 \mathrm{~min}$ and stained with $0.1 \%$ crystal violet for $20 \mathrm{~min}$. After washing in water, the colonies were counted.

\subsection{Cell Cycle Analysis}

Cells were harvested with trypsin-EDTA (Gibco) and fixed for $30 \mathrm{~min}$ in ice-cold $70 \%$ ethanol. After washing twice with PBS, cells were incubated for $30 \mathrm{~min}$ at $37{ }^{\circ} \mathrm{C}$ with $100 \mu \mathrm{g} / \mathrm{mL}$ RNase (R5125, Sigma). A final concentration of $50 \mu \mathrm{g} / \mathrm{mL}$ propidium iodide (PI) (P4170, Sigma) was added and DNA was measured with a flow cytometer (BD FACSCanto II, BD Biosciences).

\subsection{Ki-67 Analysis}

Cells were fixed in $4 \%$ paraformaldehyde for $10 \mathrm{~min}$ and permeabilized with $0.5 \%$ Triton X-100 for $10 \mathrm{~min}$. They were then incubated with Alexa Fluor 488-conjugated antiKi67 antibody (\#11882, Cell Signaling, Danvers, MA, USA) for $1 \mathrm{~h}$. Confocal images were obtained using an Olympus 1000/1200 laser-scanning confocal system (Olympus, Shinjuku, Japan). All images were saved as TIFF files, and their contrast was adjusted with Image J (NIH, Bethesda, MD, USA, v1.19m). Quantification was performed by counting the number of Ki-67-positive cells.

\subsection{MTS Assay}

MTS assay was performed using the CellTiter 96 Aqueous One Solution Cell Proliferation Assay Kit (3580, Promega, Madison, WI, USA). Briefly, cells were plated in triplicate at $1 \times 10^{4} \mathrm{mLEC}$ cells/well in 96-well culture plates in DMEM. At $24 \mathrm{~h}$ after plating, cell viability was measured using the MTS assay, according to the protocol supplied by the manufacturer.

\subsection{Annexin-V Staining}

Apoptotic cells were stained using an Annexin-V-FLUOS staining kit (\#6592, Cell Signaling), according to the protocol supplied by the manufacturer. Annexin-V-stained cells were analyzed for fluorescence intensity using a FACSCanto II Flow Cytometer (BD Biosciences).

\subsection{Senescence-Associated $\beta$-Galactosidase ( $S A \beta$-gal) Activity}

SA $\beta$-gal activity was measured using a Senescence Cells Histochemical Kit (CS0030, Sigma) according to the protocol supplied by the manufacturer. Briefly, cells were incubated for $24 \mathrm{~h}$ with or without addition of 200, 400, and $800 \mu \mathrm{M} \mathrm{H}_{2} \mathrm{O}_{2}$ (H1009-100ML, Sigma) or $5 \mathrm{mM}$ N-acetyl-cysteine (NAC) (A9165-25G, Sigma). After fixation with Fixation buffer ( $2 \%$ formaldehyde and $0.2 \%$ glutaraldehyde) for $6 \mathrm{~min}$, they were incubated with Staining Mixture at $37^{\circ} \mathrm{C}$ overnight. Cells were examined under a ZEISS Primovert microscope (ZEISS, Germany) with ZEISS Axiocam ERc 5s camera (ZEISS, Germany). The cytosol in senescent cells was stained blue. To determine the SA- $\beta$-gal activity in uteruses, uteruses were collected from mice, fixed with 10\% formaldehyde $(v / v)$ (F1635, Sigma) for 10 min at room temperature, and incubated with Staining mixture for $24 \mathrm{~h}$ at $37^{\circ} \mathrm{C}$. 


\subsection{Confocal Microscopy}

Cells were seeded on 35-mm-diameter confocal dishes (200350, SPL). For detection of mitochondrial membrane potential, cells were labeled with $250 \mathrm{nM}$ tetramethylrhodamine, methyl ester, perchlorate (TMRM, T668, Molecular Probes) in DMEM for $30 \mathrm{~min}$. Nuclei were stained with 4',6-diamidino-2-phenylindole (DAPI) (Sigma-Aldrich, St. Louis, MO, USA). Confocal images were obtained using an Olympus 1000/1200 laser-scanning confocal system (Olympus, Shinjuku, Japan) equipped with a $100 \times$ Plan Apochromat NA/1.4 oil objective and the appropriate filter combination. All images were saved as TIFF files, and their contrast was adjusted with Image J (NIH, Bethesda, MD, USA, v1.19m).

\subsection{SDS-PAGE Analysis and Immunoblotting}

Proteins were resolved by SDS-PAGE and transferred onto nitrocellulose membranes (10600001, GE Healthcare, Piscataway, NJ, USA). The membranes were then probed with the appropriate dilutions of anti-DRG2 (\#14743-1-AP, Proteintech), anti- $\beta$-actin (A5441, Sigma), anti-p53 (DO-1, sc-126, Santa Cruz), anti-phospho-p53 (Ser15, \#9284), anti-caspase-3 (\#9662), anti-PARP (46D11, \#9532), anti-phospho-histone H2A.X (Ser139, \#2577), anti-p38 MAPK (\#9212), anti-phospho-p38 MAPK (Thr180/Tyr182, \#9211), anti-p21 Waf1/Cip1 (DCS60, \#2946), and anti- $\alpha$-Tubulin (\#2144, Cell Signaling). Immunoreactivity was detected using Amersham ECL Prime (RPN2232, Cytiva). Membranes were exposed at multiple time points to ensure that the images were not saturated. If required, the band densities were analyzed with $\mathrm{NIH}$ image software and normalized by comparison with the densities of internal control $\beta$-actin bands.

\subsection{Quantitative Real-Time PCR and Semi-qRT-PCR}

Total RNA was extracted from cells using TRIzol (Thermo Fisher Scientific). Two micrograms of total RNA were reverse transcribed using oligo-dT (79237, Qiagen, Hilden, German) and MMLV reverse transcriptase (3201, Beamsbio) according to the manufacturers' instructions. A qRT-PCR was performed by monitoring the real-time increase in fluorescence of SYBR Green (MasterMix-R, Abm) using a StepOnePlus Real-Time PCR system (Applied Biosystems, Foster City, MI, USA). RT-PCR was performed using Taq polymerase $2 \times$ premix (Solgent, Daejeon, Korea) and the appropriate primers. PCR primer pairs were as follows: IL-6, 5' ${ }^{\prime}$ TAGTCCTTCCTACCCCAATTTCC- ${ }^{\prime}$ and $5^{\prime}$-TTGGTCCTTAGCCACTCCTTC-3'; VEGF-A, $5^{\prime}$-AGGCTGCTGTAACGATGAA- ${ }^{\prime}$ and $5^{\prime}$-TATGTGCTGGCTTTGGTGAG-3'; Catalase, $5^{\prime}$-GGAGGCGGGAACCCAATAG- $3^{\prime}$ and $5^{\prime}$-GTGTGCCATCTCGTCAGTGAA- ${ }^{\prime}$; GPX1, 5' -GTGCAATCAGTTCGGACACCA-3' and $5^{\prime}$-CACCAGGTCGGACGTACTTG-3'; SOD1, $5^{\prime}$-TATGGGGACAATACACAAGGCT- $3^{\prime}$ and $5^{\prime}$-CGGGCCACCATGTTTCTTAGA-3'; SOD2, $5^{\prime}$-TGGACAAACCTGAGCCCTAAG- $3^{\prime}$ and $5^{\prime}$-CCCAAAGTCACGCTTGATAGC- ${ }^{\prime}$; ARG1, $5^{\prime}$-ACAGAACTAAGCAAACGCC- $3^{\prime}$ and $5^{\prime}$-TTCATACCAGAAAGGAACTGC- $3^{\prime}$; ARG2, $5^{\prime}$-GGCTGAAGTGGTTAGTAGAG-3' and $5^{\prime}$-GGGCGTGACCGATAATG-3'; iNOS, $5^{\prime}$-GTTCTCAGCCCAACAATACAAGA- ${ }^{\prime}{ }^{\prime}$ and $5^{\prime}$-GTGGACGGGTCGATGTCAC- ${ }^{\prime}$; eNOS, $5^{\prime}$-TCAGCCATCACAGTGTTCCC-3' and 5'-ATAGCCCGCATAGCGTATCAG-3'; DRG2, $5^{\prime}$-CTCAACAGTCACACTGACAC- $3^{\prime}, 5^{\prime}$-TACCGCAACTGATAACTACA-3'; GAPDH, $5^{\prime}$ ACATCAAGAAGGTGGTGAAG- $3^{\prime}$ and $5^{\prime}$-CTGTTG CTGTAGCCAAATTC- $3^{\prime}$; IFN- $\beta 1$ : $5^{\prime}$-AAAGCAAGAGGAAAGATTGACG-3' and 5'-ACCACCATCCAGGCGTA-3'; CXCL10, $5^{\prime}$-CCAAGTGCTGCCGTCATTTTC- $3^{\prime}$ and $5^{\prime}$-GGCTCGCAGGGATGATTTCAA- $3^{\prime}$; RPLP0,

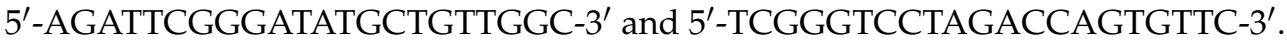

\subsection{Measurement of NO Production}

Intracellular NO was measured using 4-amino-5-methylamino-2', $7^{\prime}$-difluorofluorescein (DAF-FM) diacetate (D23844, Invitrogen, Carlsbad, CA, USA). Cells were incubated in the dark with $10 \mu \mathrm{M}$ DAF-FM diacetate for $60 \mathrm{~min}$ and then washed twice with media. Nuclei were stained with DAPI. Fluorescence was analyzed using a FACSCanto II Flow Cytometer (BD Biosciences) and an Olympus 1000/1200 laser-scanning confocal system (Olympus, Shinjuku, Japan). 


\title{
4.18. Measurement of ROS Levels
}

$\mathrm{H}_{2} \mathrm{O}_{2}$ level was measured using a ROS-Glo $\mathrm{H}_{2} \mathrm{O}_{2}$ Assay (G8820, Promega) according to the protocol supplied by the manufacturer. Briefly, $1 \times 10^{4}$ cells/well were seeded in white 96 well plates and incubated for $24 \mathrm{~h}$. After further incubation for $24 \mathrm{~h}$ with or without $8 \mu \mathrm{M}$ or $16 \mu \mathrm{M}$ doxorubicin (Sigma), the cells were incubated with $20 \mu \mathrm{L} \mathrm{H}_{2} \mathrm{O}_{2}$ substrate solution for $6 \mathrm{~h}$ and with $100 \mu \mathrm{L}$ of ROS-Glo detection solution for $20 \mathrm{~min}$. The luminescence signal obtained was measured using a SpectraMax L microplate reader (Molecular Devices).

\subsection{Statistics Analysis}

For statistical comparisons, $p$ values were determined using Student's $t$-test or one-way or two-way ANOVA. A $p$-value $<0.05$ was considered to indicate statistical significance.

\begin{abstract}
Author Contributions: J.W.P. designed the experiments and wrote the manuscript; A.-N.L. performed most of the experiments and wrote the manuscript; S.-S.P. performed the Matrigel plug assay, aorta ring assay, and in vitro tubule formation assay; M.-X.L. performed qPCR and Western blots to measure gene expression; U.H.L. and S.H.C. performed qPCR; H.R.L. and R.Y. performed blood flow analysis in the cerebral brain; B.K.K. and S.-Y.H. performed IHC of lung section; B.J.L. analyzed the results; S.-Y.H. and C.M.H. designed the experiments. All authors have read and agreed to the published version of the manuscript.
\end{abstract}

Funding: This research was funded by the National Research Foundation of Korea (NRF-2014R1A6A1030318 and NRF-2020R1F1A1058459).

Institutional Review Board Statement: The animal study protocol was approved by the Institutional Animal Care and Use Committee of the Meta-inflammation Research Center (permit number JWP-21020, 24 June 2021).

Informed Consent Statement: Not applicable.

Data Availability Statement: Not applicable.

Conflicts of Interest: The authors declare no conflict of interest.

\section{References}

1. Deanfield, J.E.; Halcox, J.P.; Rabelink, T.J. Endothelial function and dysfunction: Testing and clinical relevance. Circulation 2007, 115, 1285-1295. [CrossRef] [PubMed]

2. Galley, H.F.; Webster, N.R. Physiology of the endothelium. Br. J. Anaesth. 2004, 93, 105-113. [CrossRef] [PubMed]

3. Eilken, H.M.; Adams, R.H. Dynamics of endothelial cell behavior in sprouting angiogenesis. Curr. Opin. Cell Biol. 2010, 22, 617-625. [CrossRef] [PubMed]

4. Carmeliet, P. Angiogenesis in health and disease. Nat. Med. 2003, 9, 653-660. [CrossRef] [PubMed]

5. Rodier, F.; Campisi, J. Four faces of cellular senescence. J. Cell Biol. 2011, 192, 547-556. [CrossRef]

6. Minamino, T.; Komuro, I. Vascular Cell Senescence. Circ. Res. 2007, 100, 15-26. [CrossRef]

7. Di Leonardo, A.; Linke, S.P.; Clarkin, K.; Wahl, G.M. DNA damage triggers a prolonged p53-dependent G1 arrest and long-term induction of Cip1 in normal human fibroblasts. Genes Dev. 1994, 8, 2540-2551. [CrossRef]

8. Counter, C.M.; Avilion, A.A.; Le Feuvre, C.E.; Stewart, N.G.; Greider, C.W.; Harley, C.B.; Bacchetti, S. Telomere shortening associated with chromosome instability is arrested in immortal cells which express telomerase activity. EMBO J. 1992, 11, 1921-1929. [CrossRef]

9. Colavitti, R.; Finkel, T. Reactive Oxygen Species as Mediators of Cellular Senescence. IUBMB Life 2005, 57, 277-281. [CrossRef]

10. Davalli, P.; Mitic, T.; Caporali, A.; Lauriola, A.; D'Arca, D. ROS, Cell Senescence, and Novel Molecular Mechanisms in Aging and Age-Related Diseases. Oxidative Med. Cell. Longev. 2016, 2016, e3565127. [CrossRef]

11. Cave, A.C.; Brewer, A.C.; Narayanapanicker, A.; Ray, R.; Grieve, D.J.; Walker, S.; Shah, A.M. NADPH Oxidases in Cardiovascular Health and Disease. Antioxid. Redox Signal. 2006, 8, 691-728. [CrossRef] [PubMed]

12. Ushio-Fukai, M. Redox signaling in angiogenesis: Role of NADPH oxidase. Cardiovasc. Res. 2006, 71, 226-235. [CrossRef] [PubMed]

13. Ungvari, Z.; Kaley, G.; de Cabo, R.; Sonntag, W.E.; Csiszar, A. Mechanisms of Vascular Aging: New Perspectives. J. Gerontol. Ser. A 2010, 65A, 1028-1041. [CrossRef] [PubMed]

14. Li, H.; Förstermann, U. Nitric oxide in the pathogenesis of vascular disease. J. Pathol. 2000, 190, 244-254. [CrossRef] 
15. Ming, X.-F.; Barandier, C.; Viswambharan, H.; Kwak, B.R.; Mach, F.; Mazzolai, L.; Hayoz, D.; Ruffieux, J.; Rusconi, S.; Montani, J.-P.; et al. Thrombin Stimulates Human Endothelial Arginase Enzymatic Activity via RhoA/ROCK Pathway. Circulation 2004, 110, 3708-3714. [CrossRef] [PubMed]

16. Luiking, Y.C.; Ten Have, G.A.M.; Wolfe, R.R.; Deutz, N.E.P. Arginine de novo and nitric oxide production in disease states. Am. J. Physiol. -Endocrinol. Metab. 2012, 303, E1177-E1189. [CrossRef]

17. Berkowitz, D.E.; White, R.; Li, D.; Minhas, K.M.; Cernetich, A.; Kim, S.; Burke, S.; Shoukas, A.A.; Nyhan, D.; Champion, H.C.; et al Arginase Reciprocally Regulates Nitric Oxide Synthase Activity and Contributes to Endothelial Dysfunction in Aging Blood Vessels. Circulation 2003, 108, 2000-2006. [CrossRef]

18. Steppan, J.; Ryoo, S.; Schuleri, K.H.; Gregg, C.; Hasan, R.K.; White, A.R.; Bugaj, L.J.; Khan, M.; Santhanam, L.; Nyhan, D.; et al. Arginase modulates myocardial contractility by a nitric oxide synthase 1-dependent mechanism. Proc. Natl. Acad. Sci. 2006, 103, 4759-4764. [CrossRef]

19. Topal, G.; Brunet, A.; Walch, L.; Boucher, J.-L.; David-Dufilho, M. Mitochondrial Arginase II Modulates Nitric-Oxide Synthesis through Nonfreely Exchangeable l-Arginine Pools in Human Endothelial Cells. J. Pharmacol. Exp. Ther. 2006, 318, 1368-1374. [CrossRef]

20. Schenker, T.; Lach, C.; Kessler, B.; Calderara, S.; Trueb, B. A novel GTP-binding protein which is selectively repressed in SV40 transformed fibroblasts. J. Biol. Chem. 1994, 269, 25447-25453. [CrossRef]

21. Li, B.; Trueb, B. DRG represents a family of two closely related GTP-binding proteins. Biochim. Biophys. Acta Gene Struct. Expr. 2000, 1491, 196-204. [CrossRef]

22. Ishikawa, K.; Azuma, S.; Ikawa, S.; Semba, K.; Inoue, J. Identification of DRG family regulatory proteins (DFRPs): Specific regulation of DRG1 and DRG2. Genes Cells Devoted Mol. Cell. Mech. 2005, 10, 139-150. [CrossRef] [PubMed]

23. Ko, M.S.; Lee, U.H.; Kim, S.I.; Kim, H.J.; Park, J.J.; Cha, S.J.; Kim, S.B.; Song, H.; Chung, D.K.; Han, I.S.; et al. Overexpression of DRG2 suppresses the growth of Jurkat T cells but does not induce apoptosis. Arch. Biochem. Biophys. 2004, 422, 137-144 [CrossRef] [PubMed]

24. Song, H. Overexpression of DRG2 Increases G2/M Phase Cells and Decreases Sensitivity to Nocodazole-Induced Apoptosis. J. Biochem. 2004, 135, 331-335. [CrossRef]

25. Ko, M.S.; Kim, H.J.; Kim, H.K.; Yoon, N.A.; Lee, U.H.; Lee, S.C.; Chung, D.K.; Lee, B.J.; Suh, J.H.; Cho, W.J.; et al. Developmentally regulated GTP-binding protein 2 ameliorates EAE by suppressing the development of TH17 cells. Clin. Immunol. 2014, 150, 225-235. [CrossRef]

26. Mani, M.; Lee, U.H.; Yoon, N.A.; Kim, H.J.; Ko, M.S.; Seol, W.; Joe, Y.; Chung, H.T.; Lee, B.J.; Moon, C.H.; et al. Developmentally regulated GTP-binding protein 2 coordinates Rab5 activity and transferrin recycling. MBoC 2016, 27, 334-348. [CrossRef]

27. Mani, M.; Thao, D.T.; Kim, B.C.; Lee, U.H.; Kim, D.J.; Jang, S.H.; Back, S.H.; Lee, B.J.; Cho, W.J.; Han, I.-S.; et al. DRG2 knockdown induces Golgi fragmentation via GSK3 $\beta$ phosphorylation and microtubule stabilization. Biochim. Biophys. Acta (BBA)-Mol. Cell Res. 2019, 1866, 1463-1474. [CrossRef]

28. Vo, M.-T.; Ko, M.S.; Lee, U.H.; Yoon, E.H.; Lee, B.J.; Cho, W.J.; Ha, C.M.; Kim, K.; Park, J.W. Developmentally regulated GTPbinding protein 2 depletion leads to mitochondrial dysfunction through downregulation of dynamin-related protein 1. Biochem. Biophys. Res. Commun. 2017, 486, 1014-1020. [CrossRef]

29. Mani, M.; Lee, U.H.; Yoon, N.A.; Yoon, E.H.; Lee, B.J.; Cho, W.J.; Park, J.W. Developmentally regulated GTP-binding protein 2 is required for stabilization of Rac1-positive membrane tubules. Biochem. Biophys. Res. Commun. 2017, 493, 758-764. [CrossRef]

30. Yoon, N.A.; Jung, S.J.; Choi, S.H.; Ryu, J.H.; Mani, M.; Lee, U.H.; Vo, M.-T.; Jeon, D.Y.; Chung, S.W.; Ju Lee, B.; et al. DRG2 supports the growth of primary tumors and metastases of melanoma by enhancing VEGF-A expression. FEBS J. 2020, 287, $2070-2086$. [CrossRef]

31. Lim, H.R.; Vo, M.-T.; Kim, D.J.; Lee, U.H.; Yoon, J.H.; Kim, H.-J.; Kim, J.; Kim, S.R.; Lee, J.Y.; Yang, C.H.; et al. DRG2 Deficient Mice Exhibit Impaired Motor Behaviors with Reduced Striatal Dopamine Release. Int. J. Mol. Sci. 2020, 21, 60. [CrossRef] [PubMed]

32. Aird, W.C. Phenotypic Heterogeneity of the Endothelium. Circ. Res. 2007, 100, 158-173. [CrossRef] [PubMed]

33. Ungvari, Z.; Tarantini, S.; Kiss, T.; Wren, J.D.; Giles, C.B.; Griffin, C.T.; Murfee, W.L.; Pacher, P.; Csiszar, A. Endothelial dysfunction and angiogenesis impairment in the ageing vasculature. Nat. Rev. Cardiol. 2018, 15, 555-565. [CrossRef] [PubMed]

34. Dimri, G.P.; Lee, X.; Basile, G.; Acosta, M.; Scott, G.; Roskelley, C.; Medrano, E.E.; Linskens, M.; Rubelj, I.; Pereira-Smith, O. A biomarker that identifies senescent human cells in culture and in aging skin in vivo. Proc. Natl. Acad. Sci. 1995, 92, 9363-9367. [CrossRef]

35. Srinivas, U.S.; Tan, B.W.Q.; Vellayappan, B.A.; Jeyasekharan, A.D. ROS and the DNA damage response in cancer. Redox. Biol. 2019, 25, 101084. [CrossRef]

36. Chen, Q.; Fischer, A.; Reagan, J.D.; Yan, L.J.; Ames, B.N. Oxidative DNA damage and senescence of human diploid fibroblast cells. Proc. Natl. Acad. Sci. 1995, 92, 4337-4341. [CrossRef]

37. Fatokun, A.A.; Stone, T.W.; Smith, R.A. Hydrogen peroxide-induced oxidative stress in MC3T3-E1 cells: The effects of glutamate and protection by purines. Bone 2006, 39, 542-551. [CrossRef]

38. Gutiérrez-Uzquiza, Á.; Arechederra, M.; Bragado, P.; Aguirre-Ghiso, J.A.; Porras, A. p38 $\alpha$ Mediates Cell Survival in Response to Oxidative Stress via Induction of Antioxidant Genes: Effect on the p70S6K pathway. J. Biol. Chem. 2012, 287, 2632-2642. [CrossRef]

39. Ou, H.L.; Schumacher, B. DNA Damage Responses and P53 in the Aging Process. Blood 2018, 131, 488-495. [CrossRef] 
40. Lou, Z.; Chen, J. Cellular senescence and DNA repair. Exp. Cell Res. 2006, 312, 2641-2646. [CrossRef]

41. Coppé, J.-P.; Patil, C.K.; Rodier, F.; Sun, Y.; Muñoz, D.P.; Goldstein, J.; Nelson, P.S.; Desprez, P.-Y.; Campisi, J. SenescenceAssociated Secretory Phenotypes Reveal Cell-Nonautonomous Functions of Oncogenic RAS and the p53 Tumor Suppressor. PLOS Biol. 2008, 6, e301. [CrossRef] [PubMed]

42. He, L.; He, T.; Farrar, S.; Ji, L.; Liu, T.; Ma, X. Antioxidants Maintain Cellular Redox Homeostasis by Elimination of Reactive Oxygen Species. Cell. Physiol. Biochem. 2017, 44, 532-553. [CrossRef]

43. Hayashi, T.; Matsui-Hirai, H.; Miyazaki-Akita, A.; Fukatsu, A.; Funami, J.; Ding, Q.-F.; Kamalanathan, S.; Hattori, Y.; Ignarro, L.J.; Iguchi, A. Endothelial cellular senescence is inhibited by nitric oxide: Implications in atherosclerosis associated with menopause and diabetes. Proc. Natl. Acad. Sci. 2006, 103, 17018-17023. [CrossRef] [PubMed]

44. Kim, J.H.; Bugaj, L.J.; Oh, Y.J.; Bivalacqua, T.J.; Ryoo, S.; Soucy, K.G.; Santhanam, L.; Webb, A.; Camara, A.; Sikka, G.; et al. Arginase inhibition restores NOS coupling and reverses endothelial dysfunction and vascular stiffness in old rats. J. Appl. Physiol. 2009, 107, 1249-1257. [CrossRef] [PubMed]

45. Shin, W.; Berkowitz, D.E.; Ryoo, S. Increased arginase II activity contributes to endothelial dysfunction through endothelial nitric oxide synthase uncoupling in aged mice. Exp. Mol. Med. 2012, 44, 594-602. [CrossRef] [PubMed]

46. Ashby, J.W.; Mack, J.J. Endothelial Control of Cerebral Blood Flow. Am. J. Pathol. 2021, 191, 1906-1916. [CrossRef] [PubMed]

47. Donato, A.J.; Morgan, R.G.; Walker, A.E.; Lesniewski, L.A. Cellular and molecular biology of aging endothelial cells. J. Mol. Cell. Cardiol. 2015, 89, 122-135. [CrossRef]

48. Coppé, J.-P.; Desprez, P.-Y.; Krtolica, A.; Campisi, J. The senescence-associated secretory phenotype: The dark side of tumor suppression. Annu. Rev. Pathol. 2010, 5, 99-118. [CrossRef]

49. Lu, T.; Finkel, T. Free radicals and senescence. Exp. Cell Res. 2008, 314, 1918-1922. [CrossRef]

50. Rai, P.; Onder, T.T.; Young, J.J.; McFaline, J.L.; Pang, B.; Dedon, P.C.; Weinberg, R.A. Continuous elimination of oxidized nucleotides is necessary to prevent rapid onset of cellular senescence. Proc. Natl. Acad. Sci. 2009, 106, 169-174. [CrossRef]

51. Bringold, F.; Serrano, M. Tumor suppressors and oncogenes in cellular senescence. Exp. Gerontol. 2000, 35, 317-329. [CrossRef]

52. Liu, B.; Chen, Y.; St. Clair, D.K. ROS and p53: A versatile partnership. Free. Radic. Biol. Med. 2008, 44, 1529-1535. [CrossRef]

53. Sherr, C.J.; Roberts, J.M. CDK inhibitors: Positive and negative regulators of G1-phase progression. Genes Dev. 1999, 13, 1501-1512. [CrossRef] [PubMed]

54. Unemori, E.N.; Ferrara, N.; Bauer, E.A.; Amento, E.P. Vascular endothelial growth factor induces interstitial collagenase expression in human endothelial cells. J. Cell Physiol. 1992, 153, 557-562. [CrossRef] [PubMed]

55. Cai, H.; Harrison, D.G. Endothelial Dysfunction in Cardiovascular Diseases: The Role of Oxidant Stress. Circ. Res. 2000, 87, 840-844. [CrossRef] [PubMed]

56. Förstermann, U.; Closs, E.I.; Pollock, J.S.; Nakane, M.; Schwarz, P.; Gath, I.; Kleinert, H. Nitric oxide synthase isozymes. Characterization, purification, molecular cloning, and functions. Hypertension 1994, 23, 1121-1131. [CrossRef] [PubMed]

57. Stuehr, D.; Pou, S.; Rosen, G.M. Oxygen Reduction by Nitric-oxide Synthases. J. Biol. Chem. 2001, 276, 14533-14536. [CrossRef]

58. Landmesser, U.; Dikalov, S.; Price, S.R.; McCann, L.; Fukai, T.; Holland, S.M.; Mitch, W.E.; Harrison, D.G. Oxidation of tetrahydrobiopterin leads to uncoupling of endothelial cell nitric oxide synthase in hypertension. J. Clin. Investig. 2003, 111, 1201-1209. [CrossRef]

59. Bachetti, T.; Comini, L.; Francolini, G.; Bastianon, D.; Valetti, B.; Cadei, M.; Grigolato, P.; Suzuki, H.; Finazzi, D.; Albertini, A.; et al. Arginase pathway in human endothelial cells in pathophysiological conditions. J. Mol. Cell. Cardiol. 2004, 37, 515-523. [CrossRef]

60. Passaniti, A. Extracellular matrix-cell interactions: Matrigel and complex cellular pattern formation. Lab. Investig. 1992, 67, 804.

61. Reynolds, L.E.; Wyder, L.; Lively, J.C.; Taverna, D.; Robinson, S.D.; Huang, X.; Sheppard, D.; Hynes, R.O.; Hodivala-Dilke, K.M. Enhanced pathological angiogenesis in mice lacking $\beta 3$ integrin or $\beta 3$ and $\beta 5$ integrins. Nat. Med. 2002, 8, 27-34. [CrossRef] [PubMed]

62. Weidner, N.; Carroll, P.R.; Flax, J.; Blumenfeld, W.; Folkman, J. Tumor angiogenesis correlates with metastasis in invasive prostate carcinoma. Am. J. Pathol. 1993, 143, 401-409. [PubMed]

63. Franken, N.A.P.; Rodermond, H.M.; Stap, J.; Haveman, J.; van Bree, C. Clonogenic assay of cells in vitro. Nat. Protoc. 2006, 1, 2315-2319. [CrossRef] [PubMed] 